\title{
Demographic, ocular and associated neurological findings in corpus callosum malformations
}

\author{
Pınar Bingöl Kızıltunç ${ }^{\oplus}$, Esra Şahlı ${ }^{\circ}$, Aysun İdil ${ }^{\ominus}$, Huban Atilla ${ }^{\bullet}$ \\ Department of Ophthalmology, Ankara University Faculty of Medicine, Ankara, Turkey.
}

\begin{abstract}
Background. The corpus callosum is a primary commissural part of the brain which connects the two hemispheres. Processing sensory, motor, visuo-motor and cognitive functions are related to a healthy connection. In this study, we aimed to evaluate the ocular, neurologic and other systemic findings of corpus callosum malformations and to focus on the association between the ocular and neurological findings and the type of callosal malformation according to cranial magnetic resonance imaging (MRI).
\end{abstract}

Methods. A retrospective chart review of 57 patients with corpus callosum malformation was performed. Demographic features, neurologic, ocular and other systemic findings were noted. Patients were divided into 3 groups according to the severity of corpus callosum malformation on MRI (total agenesis, partial agenesis and hypoplasia) and also evaluated as a part of a genetic disorder/syndrome or not. The differences between demographic features, ocular and neurological findings between these 3 groups and also between syndromic and non-syndromic groups were evaluated statistically.

Results. Only $35.1 \%$ of patients had fixation and following pattern of visual acuity. Anterior segment pathologies were observed in $6.9 \%$ of patients. However, $57.9 \%$ of patients had posterior segment malformations. Only $19.3 \%$ of patients had a normal ocular alignment. There was no statistically significant difference of demographic features, ocular and neurologic findings between the 3 groups or between the syndromic/non-syndromic groups.

Conclusions. Ocular findings can be reliable depending on the severity of the corpus callosum malformations. However, delay in fixation reflex development or loss of fixation should remind us of central nervous system pathologies especially corpus callosum malformations.

Key words: agenesis, corpus callosum, hypoplasia, low vision, magnetic resonance imaging.

The corpus callosum is the largest white matter structure in the human brain and it is responsible for normal communication and cooperation between the two hemispheres. ${ }^{1}$ Interhemispheric connections have an importance for the functional integration of sensory, motor, visuo-motor and cognitive processes., ${ }^{2,3}$ Corpus callosum malformations may occur as a result of any step in the development of the corpus callosum. Disruption of neurogenesis, telencephalic midline patterning, neuronal

凶 Pınar Bingöl Kızıltunç

pinarbingol84@gmail.com

Received 17th June 2020, revised 6th August 2020, accepted 7th September 2020. migration and specification, axon guidance and post-guidance development are the steps that can be affected by the development. ${ }^{2}$ Acquired conditions, including inflammatory, vascular, demyelinating and ischemic causes can also affect the corpus callosum. ${ }^{4}$

Corpus callosum malformations can be isolated or accompany other cranial malformations. Additionally, these malformations can be associated with different genetic disorders or syndromes.

In this study, we aimed to evaluate the ocular, neurologic and other systemic findings of patients with corpus callosum malformations, to investigate concomitant syndromes and 
genetic disorders in these patients and to focus on the association between the ocular and neurological findings and type of callosal malformation according to cranial magnetic resonance imaging (MRI).

\section{Material and Methods}

This retrospective study included patients with corpus callosum malformations who were examined at Ankara University Hospital. Patients whose corpus callosum malformation were confirmed by cranial MRI were included in the study. A retrospective chart review of 57 patients was performed. Demographic features of patients, including; age, gender, follow-up period, presence of consanguinity, birth week, accompanying systemic and neurological diseases were reviewed. The presence of motor delay, intellectual disability and epilepsy were also noted. Patients were evaluated as syndromic and non-syndromic according to whether the corpus callosum malformation was part of any genetic disorder or syndrome and systemic and radiologic findings of these two groups were evaluated separately.

Ophthalmic examination findings including; visual acuities (VA), anterior and posterior segment evaluation and measurement of ocular alignment were noted. Due to the preverbal age of the study group and the presence of accompanying intellectual disability, VAs were assessed by fixation and following pattern of light. Cranial MRI results were evaluated and patients were divided into 3 groups according to the severity of the corpus callosum malformation on MRI. Patients with total corpus callosum agenesis consisted of group 1, group 2 with partial corpus callosum agenesis, group 3 with corpus callosum hypoplasia. Patients with no development of any part of the corpus callosum, were considered as total agenesis, while those with shorter anterior-posterior length as a result of missing segment(s) such as the splenium and/or the rostrum were considered as partial agenesis. In spite of normal anteroposterior length, patients with thinner than normal corpus callosum constituted the hypoplasic group. The differences between demographic features, ocular and neurological findings between these 3 groups were evaluated statistically.

\section{Statistical analyses}

Categorical parameters were presented as number and percentage. Continuous variables were presented as median and interquartile range 25-75. Categorical parameters were compared using the Chi square test and Kruskal Wallis $\mathrm{H}$ tests were used to compare continuous variables between the groups. SPSS 22 software for Windows (SPSS Inc., Chicago, IL) was used for all statistical analysis. A $P$ value less than 0.05 was considered statistically significant.

The study was conducted in line with the dictates of the Declaration of Helsinki and approved by the local ethical committee of Ankara University Faculty of Medicine (Report number: İ2-46-19, Date: 18 July 2019).

\section{Results}

Of 57 patients included, 36 (63.2\%) were male and $21(36.8 \%)$ were female. The median age was 13 (8-24) months and the median followup period was 11 (5-24) months. Ten patients $(17.5 \%)$ had a history of consanguineous marriage. The median birth week of patients was 39 (34-40) weeks. Fifty-three (93\%) patients had another concomitant neurological disorder. There exists motor delay in 51(89.5\%) patients and intellectual disability in $41(71.9 \%)$ patients. The number of patients with epilepsy was 37 $(64.9 \%)$.

Twenty patients $(35.1 \%)$ had no fixation and response to light. There was no fixation in 10 patients (17.5\%), but they had a response to light. There were 7 patients $(12.3 \%)$ with only fixation, 20 patients (35.1\%) with fixation and following pattern. When the ocular alignments of patients were evaluated, only 11 patients $(19.3 \%)$ were orthophoric. Seventeen patients $(29.8 \%)$ had wandering eye movements. Thirteen (22.8\%) 
were esotropic and 16 (28.1\%) was exotropic. In the anterior segment examinations of the patients; 2 patients (3.5\%) had ptosis, 1 (1.7\%) had megalo-cornea and blue sclera, and 1 (1.7\%) had shallow orbit. Fundus examination of 24 patients $(42.1 \%)$ was normal. The most common pathological findings were optic disc pallor and optic atrophy with a percentage of $42.1 \%$. Other findings were; optic disc hypoplasia (8.8\%), chorioretinal scars and pigmentary changes (3.5\%) and optic disc coloboma (1.7\%).

Group 1 consisted of 15 patients (26.3\%), group 2 consisted of $12(21.1 \%)$ and group 3 consisted of $30(52.6 \%)$ patients. When the differences of demographic features, ocular and neurologic findings were assessed between the 3 groups, there was no statistically significant difference in any parameters (Table I).

Corpus callosum malformation in 14 patients $(24.6 \%)$ was part of a genetic disorder or syndrome. The findings of these patients are seen in Table II. Demographic features, ocular and neurological findings were similar in patients with or without a genetic disorder / syndrome. Other accompanying systemic disorders and MRI findings of patients without a genetic disorder/syndrome are shown in Table III and Table IV.

There were 4 patients (7\%) without any neurological abnormalities. Of these, 3 (5.2\%) had isolated corpus callosum agenesis and $1(1.8 \%)$ had papillo-renal syndrome. When findings of these 3 patients with isolated corpus callosum agenesis were evaluated, all of them had normal ocular, neurologic and MRI findings except callosal agenesis. Two (3.5\%) had partial agenesis and $1(1.8 \%)$ had total agenesis. One of the patients with partial agenesis had shortduration fixation and following pattern and the other had only fixation. The patient with total agenesis had short-duration fixation and following pattern.

Table I. Demographic features, ocular and neurological findings of patients with corpus callosum total agenesis, partial agenesis and hypoplasia.

\begin{tabular}{|c|c|c|c|c|}
\hline Variable & $\begin{array}{c}\text { Group } 1 \\
\text { Total Agenesis } \\
\text { (n: } 15)\end{array}$ & $\begin{array}{c}\text { Group } 2 \\
\text { Partial Agenesis } \\
\text { (n: 12) }\end{array}$ & $\begin{array}{c}\text { Group } 3 \\
\text { Hypoplasia } \\
\text { (n: } 30)\end{array}$ & $\mathrm{p}$ \\
\hline Admittance age (month) & $19(9-43)$ & $9(5-22)$ & $14(9-22)$ & 0.243 \\
\hline Birth week & $39(39-40)$ & $39(37-40)$ & $38(33-40)$ & 0.192 \\
\hline \multicolumn{5}{|l|}{ Gender } \\
\hline Female (n) & $5(33.3)$ & $2(16.7)$ & $14(46.7)$ & \multirow{2}{*}{0.181} \\
\hline Male (n) & $10(66.7)$ & $10(83.3)$ & $16(53.3)$ & \\
\hline Consanguineous marriage (n) & $1(6.7)$ & $4(33.3)$ & $5(16.7)$ & 0.191 \\
\hline Motor retardation (n) & $14(93.3)$ & $10(83.3)$ & $27(90.0)$ & 0.725 \\
\hline Intellectual disability (n) & $11(73.3)$ & $6(50.0)$ & $24(80.0)$ & 0.143 \\
\hline Epilepsy (n) & $8(53.3)$ & $6(50.0)$ & $23(76.7)$ & 0.156 \\
\hline Neurological findings (n) & $14(93.3)$ & $10(83.3)$ & $29(96.7)$ & 0.314 \\
\hline Syndromic (n) & $6(40)$ & $3(25)$ & $5(16.7)$ & \multirow{2}{*}{0.257} \\
\hline Non-syndromic (n) & $9(60)$ & $9(75)$ & $25(83.3)$ & \\
\hline \multicolumn{5}{|l|}{ Strabismus type } \\
\hline None & $4(26.7)$ & $2(16.7)$ & $5(16.7)$ & \multirow{3}{*}{0.773} \\
\hline Esotropia & $5(33.3)$ & $3(25)$ & $5(16.7)$ & \\
\hline Exotropia & $3(20)$ & $4(33.3)$ & $9(30)$ & \\
\hline Wandering eye movements & $3(20)$ & $3(25)$ & $11(36.7)$ & \\
\hline \multicolumn{5}{|l|}{ Fundus pathology } \\
\hline Normal & $5(33.4)$ & $8(66.7)$ & $11(36.7)$ & \multirow{2}{*}{0.128} \\
\hline Pathologic & $10(66.7)$ & $4(33.3)$ & $19(63.3)$ & \\
\hline
\end{tabular}


Table II. Findings of patients with corpus callosum malformation as part of a genetic disorder or syndrome.

\begin{tabular}{|c|c|c|c|c|}
\hline $\begin{array}{l}\text { Patients age (month) } \\
\text { /gender/type of } \\
\text { corpus callosum } \\
\text { malformation }\end{array}$ & $\begin{array}{l}\text { Genetic disorder or } \\
\text { syndrome }\end{array}$ & Ocular findings & Systemic findings & Radiological findings \\
\hline \multirow{3}{*}{$\begin{array}{l}9 \mathrm{~m} / \text { male / } \\
\text { Hypoplasia }\end{array}$} & \multirow[t]{3}{*}{ 18q deletion } & Megalocornea & Microcephaly & Delay in myelination \\
\hline & & Blue sclera & Motor retardation & Dilatation of lateral \\
\hline & & & Intellectual disability & \\
\hline \multirow{6}{*}{$\begin{array}{l}\text { 19m / male / Total } \\
\text { agenesis }\end{array}$} & \multirow{6}{*}{$\begin{array}{l}\text { Dandy-Walker } \\
\text { syndrome }\end{array}$} & \multirow[t]{6}{*}{ Optic atrophy } & \multirow{6}{*}{$\begin{array}{l}\text { Hydrocephalus } \\
\text { Motor retardation } \\
\text { Intellectual disability }\end{array}$} & Hypoplasia of \\
\hline & & & & inferior cerebellar \\
\hline & & & & hemispheres \\
\hline & & & & $\begin{array}{l}\text { Enlargement of } \\
\text { ventricles }\end{array}$ \\
\hline & & & & Colpocephaly \\
\hline & & & & Cerebral atrophy \\
\hline \multirow[t]{4}{*}{$\begin{array}{l}49 \mathrm{~m} / \text { male / Total } \\
\text { agenesis }\end{array}$} & \multirow[t]{4}{*}{ Dudley syndrome } & \multirow[t]{4}{*}{ Optic atrophy } & $\begin{array}{l}\text { Macrocephaly } \\
\text { Deafness }\end{array}$ & $\begin{array}{l}\text { Dysmyelination of } \\
\text { white matter }\end{array}$ \\
\hline & & & Motor retardation & Cerebral and \\
\hline & & & Intellectual disability & cerebellar atrophy \\
\hline & & & Hypothyroidism & \\
\hline \multirow{4}{*}{$\begin{array}{l}13 \mathrm{~m} / \text { female / } \\
\text { Hypoplasia }\end{array}$} & \multirow[t]{4}{*}{ Aicardi syndrome } & Chorioretinal scars & Infantile spasm & Chronic subdural \\
\hline & & \multirow{3}{*}{$\begin{array}{l}\text { Retinal pigmentary } \\
\text { changes }\end{array}$} & \multirow{3}{*}{$\begin{array}{l}\text { Motor retardation } \\
\text { Intellectual disability }\end{array}$} & $\begin{array}{l}\text { hematoma at left } \\
\text { frontal cortex }\end{array}$ \\
\hline & & & & $\begin{array}{l}\text { Dilatation of lateral } \\
\text { ventricles }\end{array}$ \\
\hline & & & & $\begin{array}{l}\text { Loss of volume in } \\
\text { periventricular white } \\
\text { matter }\end{array}$ \\
\hline \multirow{4}{*}{$\begin{array}{l}\text { 10m / male / Partial } \\
\text { agenesis }\end{array}$} & \multirow{4}{*}{$\begin{array}{l}\text { de Morsier } \\
\text { syndrome }\end{array}$} & \multirow{4}{*}{$\begin{array}{l}\text { Optic atrophy } \\
\text { Optic nerve } \\
\text { hypoplasia }\end{array}$} & Epilepsy & Loss of volume in \\
\hline & & & Motor retardation & periventricular white \\
\hline & & & Intellectual disability & matter \\
\hline & & & Contracture of feet & $\begin{array}{l}\text { Bilaterally thinning } \\
\text { of optic nerve and } \\
\text { chiasm }\end{array}$ \\
\hline \multirow{4}{*}{$\begin{array}{l}15 \mathrm{~m} / \text { female / } \\
\text { Hypoplasia }\end{array}$} & \multirow[t]{4}{*}{ Pearson syndrome } & \multirow[t]{4}{*}{ Chorioretinal scar } & Sideroblastic anemia & Delay in myelination \\
\hline & & & $\begin{array}{l}\text { Mitochondrial } \\
\text { myopathy }\end{array}$ & Large cerebral sulci \\
\hline & & & Motor retardation & \\
\hline & & & Intellectual disability & \\
\hline \multirow{8}{*}{$\begin{array}{l}5 \mathrm{~m} / \text { male / Total } \\
\text { agenesis }\end{array}$} & \multirow[t]{8}{*}{ Under investigation } & \multirow{8}{*}{$\begin{array}{l}\text { Optic atrophy } \\
\text { Strabismus }\end{array}$} & Colpocephaly & Shallow silvian \\
\hline & & & Microcephaly & fissure \\
\hline & & & Deafness & Decrease in normal \\
\hline & & & Motor retardation & \\
\hline & & & Intellectual disability & Colpocephaly \\
\hline & & & Hypertrichosis & \\
\hline & & & Cerebral palsy & \\
\hline & & & Cryptorchidism & \\
\hline
\end{tabular}


Table II. Continued.

Patients age (month)

/gender/type of corpus callosum malformation
Genetic disorder or syndrome

Ocular findings Systemic findings Radiological findings

\begin{tabular}{|c|c|c|c|c|}
\hline $\begin{array}{l}4 \mathrm{~m} / \text { female / Total } \\
\text { agenesis }\end{array}$ & Aicardi syndrome & $\begin{array}{l}\text { Retinal pigmentary } \\
\text { changes }\end{array}$ & $\begin{array}{l}\text { Hydrocephalus } \\
\text { Motor retardation } \\
\text { Intellectual disability } \\
\text { Infantile spasm }\end{array}$ & $\begin{array}{l}\text { Periventricular } \\
\text { encephalomalacia }\end{array}$ \\
\hline $\begin{array}{l}19 \mathrm{~m} / \text { female / } \\
\text { Hypoplasia }\end{array}$ & $\begin{array}{l}18^{\text {th }} \text { exon c40936> } \\
\text { T nonsense } \\
\text { heterozygot } \\
\text { mutation }\end{array}$ & $\begin{array}{l}\text { Ptosis } \\
\text { Optic disc } \\
\text { hypoplasia }\end{array}$ & $\begin{array}{l}\text { Syndromic face } \\
\text { Esophageal atresia }\end{array}$ & Delay in myelination \\
\hline
\end{tabular}

$1 \mathrm{~m} /$ female / Partial Under investigation Shallow orbit agenesis

Cleft palate

Agenesis of left

kidney

Ventricular septal

defect

Malnutrition

Motor retardation

Intellectual disability

\begin{tabular}{|c|c|c|c|c|}
\hline $\begin{array}{l}36 \mathrm{~m} / \text { female / } \\
\text { Hypoplasia }\end{array}$ & $\begin{array}{l}6 \mathrm{q} \text { deletion } \\
\text { (Interstitial deletion } \\
\text { at the region of } \\
\mathrm{q} 21-\mathrm{q} 22.33 \text { ) }\end{array}$ & Optic atrophy & $\begin{array}{l}\text { Scoliosis } \\
\text { Hallux valgus } \\
\text { Tetralogy of Fallot }\end{array}$ & - \\
\hline $\begin{array}{l}26 \mathrm{~m} / \text { male / Partial } \\
\text { agenesis }\end{array}$ & $\begin{array}{l}\text { Pierre Robin } \\
\text { syndrome }\end{array}$ & $\begin{array}{l}\text { Ptosis } \\
\text { Optic atrophy } \\
\text { Strabismus } \\
\text { Retinal pigmentary } \\
\text { changes }\end{array}$ & $\begin{array}{l}\text { Micrognatia } \\
\text { Laryngomalacia } \\
\text { High arched palate } \\
\text { Motor retardation } \\
\text { Intellectual disability }\end{array}$ & $\begin{array}{l}\text { Loss of volume in } \\
\text { white matter } \\
\text { Deformation of } \\
\text { vermis and pons }\end{array}$ \\
\hline $\begin{array}{l}43 \mathrm{~m} / \text { female / Total } \\
\text { agenesis }\end{array}$ & Under investigation & - & $\begin{array}{l}\text { Cleft lip/ palate } \\
\text { Deafness } \\
\text { Pilor obstruction } \\
\text { Motor retardation } \\
\text { Intellectual disability }\end{array}$ & - \\
\hline $\begin{array}{l}15 \mathrm{~m} / \text { female / } \\
\text { Hypoplasia }\end{array}$ & $\begin{array}{l}\text { Papillorenal } \\
\text { syndrome } \\
\text { Chromosome } \\
10 \text { deletion } \\
\text { (q25.1-q26.13) }\end{array}$ & $\begin{array}{l}\text { Optic disc } \\
\text { coloboma }\end{array}$ & $\begin{array}{l}\text { Deafness } \\
\text { Hypothyroidism } \\
\text { Motor retardation } \\
\text { Intellectual disability }\end{array}$ & $\begin{array}{l}\text { Agenesis of septum } \\
\text { pellucidum }\end{array}$ \\
\hline
\end{tabular}


Table III. Accompanying systemic disorders of patients without a genetic disorder/syndrome.

\begin{tabular}{ll}
\hline Disorder & Number of patients $\mathrm{n} / \%$ \\
\hline Hydrocephalus & $8 / 18.6$ \\
Cerebral palsy & $4 / 9.3$ \\
Microcephaly & $3 / 7$ \\
Hydrocele & $3 / 7$ \\
Cardiac pathology & $2 / 4.7$ \\
Meningomyelocele & $2 / 4.7$ \\
Otism & $1 / 2.3$ \\
Macrocephaly & $1 / 2.3$ \\
Hypothyroidism & $1 / 2.3$ \\
Scoliosis & $1 / 2.3$ \\
Hearing loss & $1 / 2.3$ \\
\hline
\end{tabular}

Table IV. Radiological findings of patients without a genetic disorder/syndrome.

\begin{tabular}{ll}
\hline Radiological findings & Number of patients $\mathrm{n} / \%$ \\
\hline Colpocephaly & $10 / 23.3$ \\
Loss of volume in periventricular white matter & $9 / 20.9$ \\
Diffuse loss of volume in white matter & $7 / 16.3$ \\
Oligogyria & $4 / 9.3$ \\
Chiari malformation & $3 / 6.9$ \\
Defect of septum pellucidum & $3 / 6.9$ \\
Hypoplasia of inferior vermis & $2 / 4.6$ \\
Cerebellar hypoplasia & $2 / 4.6$ \\
Loss of volume in brainstem & $1 / 2.3$ \\
\hline
\end{tabular}

\section{Discussion}

In this study, we evaluated the systemic and ocular findings in patients with corpus callosum malformations including agenesis and hypoplasia and also assessed the relationship between genetic and radiological findings. Anterior segment pathologies were observed in only $6.9 \%$ of patients. However, $57.9 \%$ of patients had posterior segment malformations. Only $19.3 \%$ of patients had a normal ocular alignment. When we evaluated the differences of all demographic, neurologic and ocular parameters between the 3 groups, there was no statistically significant difference. In addition, whether the corpus callosum malformation was part of a genetic disorder or syndrome, did not make any difference on these findings.

The corpus callosum develops between the 8th and the $20^{\text {th }}$ week of gestation..$^{5}$ Although the number of callosal fibers and final shape of the corpus callosum are completed by the $20^{\text {th }}$ week of gestation, axonal growth continues until 2 months after birth ${ }^{6}$ and structural changes due to fiber myelination, redirection and pruning, continue in childhood and adolescence. ${ }^{7}$ Since the myelin tissue, which is the protective tissue of the corpus callosum, is less than in other brain tissues, the corpus callosum is affected more easily by external factors. Different studies found that the corpus callosum is one of the most common parts of the brain affected by demyelination and axonal loss. ${ }^{8,9}$ Therefore, the corpus callosum may also be affected by postpartum pathologies such as hydrocephalus, ischemia and demyelination. With an embryologic developmental aspect, the eye is required for the development of callosal terminals. ${ }^{10,11}$ Additionally, the corpus callosum is necessary for the maturation of the visual cortex. $^{12}$ 
This interhemispheric connection has a role in visual perception. There exists a connection between callosal fibers and the visual cortex. Neuronal changes caused by callosal inputs in the visual cortex have been demonstrated by electrophysiological tests. ${ }^{13}$ If these inputs are eliminated by cooling or unilateral GABA injection into the hemisphere, a decrease in neuronal response occurs in the visual cortex. Therefore, callosal fibers play a role in the visual process. Additionally, it is thought to have a complex relationship between the parts of the corpus callosum and visual function. Kwinta et al. ${ }^{14}$ found that there is a correlation between the function of rostrum, genu and body of the corpus callosum and stereoscopic vision. Dougherty et al. ${ }^{15}$ showed projections between the occipital lobe and splenium of the corpus callosum. These projections may differ, as the shape and location of the splenium vary between individuals. If these projections are damaged, visual deficits such as visual recognition and identification can be seen. In our study, because of the age of patients and accompanying intellectual disability, we could only evaluate the visual functions of patients by measuring fixation and following patterns. Thirty-five $\%$ of patients had no fixation and response to the light. Only $33.3 \%$ of patients had normal fixation and following pattern.

Although corpus callosum malformations can be isolated, they are more commonly associated with other cerebral or extra-cerebral abnormalities. ${ }^{16}$ Therefore, it is difficult to say that the cause of neurological and ocular disorders in these patients is mainly due to corpus callosum malformations. Existing neurological and ocular disorders may also be due to accompanying cerebral pathologies. Therefore, in order to evaluate the effects of corpus callosum pathologies, it would be more appropriate to investigate patients with isolated corpus callosum malformation without any accompanying cerebral or extra-cerebral abnormalities. In our study, $94.7 \%$ of patients had other cerebral abnormalities. The most common pathology associated with the corpus callosum malformation was hydrocephalus $(18.6 \%)$ and cerebral palsy $(9.3 \%)$ in patients without a genetic disorder or syndrome. Additionally, colpocephaly (23.3\%) and loss of volume in periventricular white matter $(20.9 \%)$ were the most common radiological findings in this group. Only 3 of 57 patients (5.3\%) had an isolated corpus callosum malformation with a normal neurologic examination and MRI findings except callosal agenesis. These 3 patients had normal anterior and posterior segment findings with a good ocular alignment. While one patient with total agenesis had a weak fixation and follow-up pattern, one patient with partial agenesis had only fixation. Although these findings may suggest that the connections of the corpus callosum may differ between individuals, they cannot be conclusive because of the small number of patients.

When we evaluated the association between the ocular and neurological findings and type of callosal malformation, there was no difference between the 3 groups. Because of the complex structure of the corpus callosum and accompanying other cerebral pathologies, these groups may have similar findings. It would be more appropriate to evaluate these 3 groups in patients with isolated corpus callosum malformations. Moutard et al. ${ }^{17}$ evaluated the neurological findings of isolated corpus callosum agenesis and they showed that isolated corpus callosum agenesis could have a favorable outcome that was independent of corpus callosum agenesis type. In our study, one of the patients with isolated corpus callosum agenesis had total agenesis with a visual function of weak fixation and following pattern and the other had partial agenesis with only fixation. These findings suggest that isolated corpus callosum malformations should be evaluated in terms of ocular findings.

Corpus callosum malformations can also be seen as a part of any genetic disorder or syndrome. More than 200 genetic syndromes with corpus callosum malformations have been described. ${ }^{2}$ Rubinstein-Taybi, Marden-Walker syndrome, Aicardi syndrome, Bardet-Biedl syndrome, 
Joubert syndrome and septo-optic dysplasia are some of these syndromes. Thirty- forty-five \% of patients with corpus callosum agenesis had a genetic disorder. Of these, the cause of 20$35 \%$ is single gene mutations. ${ }^{16,18}$ Some of these syndromes have ocular findings, including aniridia, iris and optic nerve coloboma, optic nerve hypoplasia, chorioretinal lacunae and congenital fibrosis of the extraocular muscles. ${ }^{19-22}$ In our study, 14 patients (24.6\%) had a genetic disorder or syndrome. Ocular findings observed in these patients were as follows: megalocornea, blue sclera, ptosis, shallow orbit, optic disc atrophy and hypoplasia, chorioretinal scar and pigmentary changes.

One of the main limitations of this study was the small number of patients with isolated corpus callosum malformations. Most patients had other accompanying cerebral pathologies. Therefore, the effect of the corpus callosum on visual functions could not be evaluated as isolated. In addition, visual functions of the corpus callosum such as fusion, stereopsis and binocular visual field could not be evaluated because of the age and mental status of patients.

This study has importance in determining the frequency of concomitant ocular, neurological and syndromic disorders in patients with corpus callosum malformations, due to the large study population. Children with loss of fixation or delay in fixation reflex development should be evaluated for central nervous system pathologies including corpus callosum malformations. Additionally, in the presence of accompanying neurological pathologies in children with visual dysfunction, further neuroradiological examinations should be performed. This study will be a guide for a future study, including the evaluation of visual functions of patients with isolated corpus callosum malformation according to the type and severity of the corpus callosum malformation.

\section{REFERENCES}

1. Devinsky O, Laff R. Callosal lesions and behavior: history and modern concepts. Epilepsy Behav 2003; 4: 607-617.

2. Edwards TJ, Sherr EH, Barkovich AJ, Richards LJ. Clinical, genetic and imaging findings identify new causes for corpus callosum development syndromes. Brain 2014; 137(Pt 6): 1579-1613.

3. Palmer EE, Mowat D. Agenesis of the corpus callosum: a clinical approach to diagnosis. Am J Med Genet C Semin Med Genet 2014; 166C: 184-197.

4. Garg N, Reddel SW, Miller DH, et al. The corpus callosum in the diagnosis of multiple sclerosis and other CNS demyelinating and inflammatory diseases. J Neurol Neurosurg Psychiatry 2015; 86: 1374-1382.

5. Zamponi N, Rossi B, Messori A, Polonara G, Regnicolo L, Cardinali C. Joubert syndrome with associated corpus callosum agenesis. Eur J Paediatr Neurol 2002; 6: 63-66.

6. Innocenti GM, Price DJ. Exuberance in the development of cortical networks. Nat Rev Neurosci 2005; 6: 955-965.

7. Luders E, Thompson PM, Toga AW. The development of the corpus callosum in the healthy human brain. J Neurosci 2010; 30: 10985-10990.

8. Pelletier J, Suchet L, Witjas T, et al. A longitudinal study of callosal atrophy and interhemispheric dysfunction in relapsing-remitting multiple sclerosis. Arch Neurol 2001; 58: 105-111.

9. Barkhof FJ, Elton M, Lindeboom J, et al. Functional correlates of callosal atrophy in relapsing-remitting multiple sclerosis patients. A preliminary MRI study. J Neurol 1998; 245: 153-158.

10. Olavarría JF, Laing R, Hiroi R, Lasiene J. Topography and axon arbor architecture in the visual callosal pathway: effects of deafferentation and blockade of N-methyl-D-aspartate receptors. Biol Res 2008; 41: 413-424.

11. Sorensen SA, Jones TA, Olavarria JF. Neonatal enucleation reduces the proportion of callosal boutons forming multiple synaptic contacts in rat striate cortex. Neurosci Lett 2003; 351: 17-20.

12. Pietrasanta M, Restani L, Caleo M. The corpus callosum and the visual cortex: plasticity is a game for two. Neural Plast 2012; 2012: 838672. 
13. Payne BR, Siwek DF, Lomber SG. Complex transcallosal interactions in visual cortex. Vis Neurosci 1991; 6: 283-289.

14. Kwinta P, Herman-Sucharska I, Lesniak A, et al. Relationship between stereoscopic vision, visual perception, and microstructure changes of corpus callosum and occipital white matter in the 4-yearold very low birth weight children. Biomed Res Int 2015; 2015: 842143.

15. Dougherty RF, Ben-Shachar M, Bammer R, Brewer AA, Wandell BA. Functional organization of human occipital-callosal fiber tracts. Proc Natl Acad Sci U S A $2005 ; 102: 7350-7355$.

16. Schell-Apacik CC, Wagner K, Bihler $M$, et al. Agenesis and dysgenesis of the corpus callosum: clinical, genetic and neuroimaging findings in a series of 41 patients. Am J Med Genet A 2008; 146A: 2501-2511.

17. Moutard ML, Kieffer V, Feingold J, et al. Agenesis of corpus callosum: prenatal diagnosis and prognosis. Childs Nerv Syst 2003; 19: 471-476.
18. Bedeschi MF, Bonaglia MC, Grasso R, et al. Agenesis of the corpus callosum: clinical and genetic study in 63 young patients. Pediatr Neurol 2006; 34: 186-193.

19. Abouzeid H, Youssef MA, ElShakankiri N, Hauser P, Munier FL, Schorderet DF. PAX6 aniridia and interhemispheric brain anomalies. Mol Vis 2009; 15: 2074-2083.

20. Graham JM Jr, Wheeler P, Tackels-Horne D, et al. A new X-linked syndrome with agenesis of the corpus callosum, mental retardation, coloboma, micrognathia, and a mutation in the Alpha 4 gene at Xq13. Am J Med Genet A 2003; 123A: 37-44.

21. Kelberman D, Dattani MT. Septo-optic dysplasia novel insights into the aetiology. Horm Res 2008; 69: 257-265.

22. Demer JL, Clark RA, Tischfield MA, Engle EC. Evidence of an asymmetrical endophenotype in congenital fibrosis of extraocular muscles type 3 resulting from TUBB3 mutations. Invest Ophthalmol Vis Sci 2010; 51: 4600-4611. 